Available online on 15.3.2018 at http://ujpr.org
Universal Journal of Pharmaceutical Research
An International Peer Reviewed Journal
Open access to Pharmaceutical research

\title{
IDENTIFICATION AND PRIORITIZATION OF BARRIERS TO IMPLEMENT THE GREEN HOSPITAL STANDARDS AT IMAM HASSAN MOJTABA HOSPITAL IN DARAB
}

\author{
Abbas Yazdanpanah ${ }^{1}$ (D), Marjan Yazdi ${ }^{1}$ (D), Parviz Aghayii Barzabad ${ }^{2}$ (D) \\ ${ }^{1}$ Department of Healthcare Management, Marvdasht Branch, Islamic Azad University, Marvdasht, Iran. \\ ${ }^{2}$ Department of Medical Education Management, Cellular and Molecular Research Center, Yasuj University of Medical Sciences \\ Yasuj, Iran.
}

\section{ABSTRACT}

Objectives: One of the most important issues being discussed globally is the environmental protection. The study and review of the standard of the Green Hospital is of particular importance because hospitals are the second most polluting industry. Therefore, the purpose of this study was to identify and prioritize the barriers to implement Green Hospital standards at Imam Hassan Mojtaba Hospital in Darab.

Methods: The present study was descriptive-applied. The statistical population in this study was a number of knowledgeable personnel and managers regarding the standards of Green Hospital in Darab, and the number of samples was 8 people who were selected through purposeful sampling. The tools used to collect information in this research were interviews, questionnaires, tables, databases and computer networks. In addition, the multi-criteria decision-making model of TOPSIS was used in this research for component-based ranking related to the research. Data were gathered through questionnaires and interviews with personnel and managers. Then, Excel software was used to analyze the statistical data.

Results: The results showed that conceptual model included five groups of environmental factors, technological factors, awareness and knowledge factors, economic factors and human resource factors. Meanwhile, the barriers to knowledge with the value of $\mathrm{CL}=1$ were identified as the most important ones for implementation of the Green Hospital standards in Imam Hassan Mojtaba Hospital in Darab. The technology barriers index with CL value of 0.690 was assigned in the second place, then the human barriers index with $C L=0.493$, economic barriers with $C L=0.39$ and environmental barriers with $C L=0.223$ were the next priorities. Conclusion: According to the results of the present study, the barriers to knowledge and awareness were identified as the most important ones for the implementation of the Green Hospital standards in Imam Hassan Mojtaba Hospital of Darab. Another result of this study was the impact of lack of infrastructure for technology Information as one of the most important barriers to implement Green Hospital standards.

Keywords: Barriers, Green hospital, standard.

Article Info: Received 16 December 2017; Revised 2 February; Accepted 4 March, Available online 15 March 2018

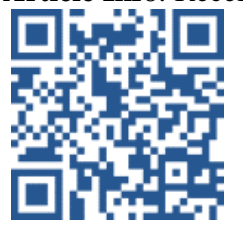

\section{Cite this article-}

Abbas Yazdanpanah, Marjan Yazdi, Parviz Aghayii Barzabad. Identification and prioritization of barriers to implement the Green hospital standards at Imam Hassan Mojtaba hospital in Darab. Universal Journal of Pharmaceutical Research 2018; 3(1): 43-48.

DOI: http://doi.org/10.22270/ujpr.v3i1.R8

Address for Correspondence

Abbas Yazdanpanah, Department of Healthcare Management, Marvdasht Branch, Islamic Azad University, Marvdasht, Iran. E-mail: abbas_yaz@miau.ac.ir

\section{INTRODUCTION}

Hospitals and healthcare staffs with sustainable and economical environmental approaches can be the main promoters of environmental protection in a broader range such as the global community. Hospitals and healthcare systems can contribute to sustainability, greater equity and environmental protection through investing on healthy buildings, green purchases and sustainable operations, in addition to coping with climate change. Hospitals and healthcare systems can enhance their economic position and moral standing in the community by helping achieve the millennium development goals in terms of health, sustainability and green economy. In addition to its traditional role in delivering high-quality care, the healthcare sector can create common health, economic and social benefits through reducing its environmental impacts and improve public health ${ }^{1}$. There is no universal standard for the definition of "green and healthy hospitals". But in principle, it can be defined as follows: A green and healthy hospital is one that promotes the health of the people by continually reducing environmental 
outcomes and eliminating their contribution to the burden of disease. The green and healthy hospital knows the link between human health and the environment, and shows such recognition through its management, strategy, and operation. It links its needs with environmental measures, and reflects its commitment to the environment with actively contributing to the development and strength of the community's environment, equality in the health and the green economy by adopting preventive measures. There is no uniform pattern for green and healthy hospitals, and many hospitals and healthcare systems worldwide have taken measures to reduce environmental footprint, participate in public health and save costs simultaneously ${ }^{2}$. There are many factors that are effective on barriers to implement hospital standards. Esa et al., believe that lack of awareness; education and information about the benefits of green hospitals are the most important barriers to the implementation of green hospitals ${ }^{3}$. From the perspective of Luthra et al., lack of knowledge of customers, high cost of implementation, senior management's non-commitment, government's lack of support, lack of organizational encouragement were identified as the most important barriers to the implementation of green hospital standards ${ }^{4}$. Dashore et al. believed that the obstacles to implementation of the Green Hospital are human factors, organizational factors, and intra-organization factors ${ }^{5}$.

The results obtained in a previous study shows that factors such as the lack of governmental regulations and laws, lack of knowledge and experience, the costs of implementing green activities, unacceptance of advances in new technology, non-commitment to high level management, lack of management plans for transportation and logistics, market competition and uncertainty, financial implications, lack of education about green activity are the most important in the nonimplementation of green hospital standards. This means that increasing the weight of each of these factors will reduce the implementation of green hospital standards ${ }^{6}$. Omidvar et al., stated that the factors of lack of support of senior and middle managers of the organization, the lack of appropriate information and communication technology infrastructure to facilitate the implementation of green activity, the difficulty of coordinating and organizing units in the implementation of activities, high costs of implementation, lack of proper incentives from the government to achieve green activities, lack of knowledge and education on environmental issues have an inverse relationship with the implementation of Green Hospital standards ${ }^{7}$. This means that with increase of each of these factors, the feasibility of implementing green hospital standards will be reduced. Considering the importance of green activities for hospitals from environmental, economic and cost savings viewpoints, increasing income and profits and identifying the obstacles to implementation of Green Hospital standards in hospitals, the researcher seeks to identify and prioritize Green Hospital standards in Darab Hospital.

\section{METHODS}

The present study was descriptive-applied. It is applicable because the results can be used by managers, decision-makers and planners of hospitals. The statistical population in this research included a number of knowledgeable personnel and managers in Imam Hassan Mojtaba in Darab in the field of green hospital standards and the number of samples was 8 people who were selected through purposeful sampling. The tools used to collect information in this research were interviews, questionnaires, tables, databases and computer networks. Data were gathered through a questionnaire and interview with knowledgeable staff and managers of Darab Hospital. All ethical issues in the research were considered. These included receiving a letter of introduction from the Islamic Azad University, Marvdasht branch, presenting it to healthcare system in the city of Darab, ensuring the hospital authorities to keep the information confidential, and explaining the interviewees about the purpose of the research. Also, all individuals selected for interviewing and filling in the questionnaire were completely free to provide information and in case of dissatisfaction, the person was removed from interviewing and filling the questionnaire and someone else was replaced. Honesty has been considered in the analysis of data. In this research, the multi-criteria decision-making model of TOPSIS was used for component-based ranking in the research. This technique, first proposed by Hwang and Yoon, is one of the most important multiple attribute decision-making techniques for dealing with world affairs ${ }^{6}$. In ideal point-based methods, the sorting of a set of options is based on their separation from the ideal point. The Technique for Order of Preference by Similarity to Ideal Solution (TOPSIS) is one of the most commonly used methods. Based on this technique, the best option is one that is simultaneously the closest unit to the ideal point and the farthest unit from the negative ideal point, TOPSIS both requires a steady increase in utility (the larger the value of the attribute is, the better the option will be) and a steady decrease in utility (the smaller the attribute value is the better the option will be). One of the important advantages of this method is that both objective and subjective criteria and indicators can be used simultaneously. However, in this model for mathematical calculations, all values assigned to the criteria were quantitative, and if they are qualitatively attributed to the criteria, they should be converted into quantitative values. Although the TOPSIS method can be used both in Raster and SIG, this technique is particularly suited to the structure of the Raster data. To analyze the statistical data, Excel software was used.

\section{RESULTS AND DISCUSSION}

The results have been set in two general sections. In the first section, data analysis was done using content analysis method. In the second part, the statistical methods used to analyze the data from the questionnaire have been studied. 
Table 1: Conceptual categories regarding human barriers' theme.

\begin{tabular}{|c|c|c|c|c|c|c|}
\hline $\begin{array}{c}\text { Main } \\
\text { theme no. }\end{array}$ & $\begin{array}{c}\text { Description of } \\
\text { main theme }\end{array}$ & $\begin{array}{c}\text { Sub- } \\
\text { theme no. }\end{array}$ & $\begin{array}{c}\text { Description of } \\
\text { sub-theme }\end{array}$ & $\begin{array}{c}\text { Concept } \\
\text { no. }\end{array}$ & $\begin{array}{c}\text { Description of } \\
\text { concept }\end{array}$ & Code no. \\
\hline \multirow[t]{15}{*}{$\mathrm{A}$} & Human barriers & A1 & $\begin{array}{l}\text { Lack of support } \\
\text { of managers }\end{array}$ & A1-1 & $\begin{array}{c}\text { Financial support of } \\
\text { managers }\end{array}$ & $\begin{array}{l}\text { E2-A2-C3- } \\
\text { F2-G4 }\end{array}$ \\
\hline & & & & A1-2 & $\begin{array}{c}\text { Emotional support of } \\
\text { managers }\end{array}$ & -I2-H4-D3 \\
\hline & & $\mathrm{A} 2$ & $\begin{array}{l}\text { Unwillingness } \\
\text { to change }\end{array}$ & A2-1 & Satisfaction & $\begin{array}{c}\text { B4-C3-F3- } \\
\text { H2-J3 }\end{array}$ \\
\hline & & & & A2-2 & $\begin{array}{l}\text { Resistance against } \\
\text { change }\end{array}$ & E4-H3-C3 \\
\hline & & & & A2-3 & $\begin{array}{l}\text { Cost of change } \\
\text { implementation }\end{array}$ & F3-H2-J3 \\
\hline & & & & A2-4 & $\begin{array}{l}\text { inattention to the } \\
\text { environment }\end{array}$ & B4-C3-F3 \\
\hline & & & & A $2-5$ & $\begin{array}{c}\text { Concerning about } \\
\text { change }\end{array}$ & $\mathrm{H} 3-\mathrm{C} 3$ \\
\hline & & A3 & $\begin{array}{c}\text { Lack of } \\
\text { cooperation }\end{array}$ & A3-1 & $\begin{array}{l}\text { Non-alignment of } \\
\text { sectors }\end{array}$ & $\begin{array}{l}\text { A2-C3-F2- } \\
\text { G4 }\end{array}$ \\
\hline & & & & A3-2 & Lack of facilities & C3-F3-G4 \\
\hline & & & & A3-3 & Lack of attention & $-\mathrm{C} 3-\mathrm{F} 2-\mathrm{G} 4$ \\
\hline & & & & A3-4 & $\begin{array}{l}\text { Lack of social } \\
\text { responsibility }\end{array}$ & C3 -G4 \\
\hline & & A4 & $\begin{array}{l}\text { Inattention to } \\
\text { strategic goals }\end{array}$ & A4-1 & $\begin{array}{l}\text { Not considering green } \\
\text { hospital in goals }\end{array}$ & A2- G4 \\
\hline & & & & A4-2 & $\begin{array}{l}\text { Non-alignment of all } \\
\text { goals }\end{array}$ & $\mathrm{H} 3-\mathrm{C} 3$ \\
\hline & & A5 & Human resource & A5-1 & $\begin{array}{l}\text { Lack of trained } \\
\text { resource }\end{array}$ & $\begin{array}{c}\text { B4-C3-F3- } \\
\text { H2-J3 }\end{array}$ \\
\hline & & & & A5-2 & Non-commitment & E4-H3-C3 \\
\hline
\end{tabular}

Table 2: Conceptual categories regarding economic barriers' theme.

\begin{tabular}{|c|c|c|c|c|c|c|}
\hline $\begin{array}{c}\text { Main theme } \\
\text { no. }\end{array}$ & $\begin{array}{c}\begin{array}{c}\text { Description } \\
\text { of main } \\
\text { theme }\end{array} \\
\end{array}$ & $\begin{array}{c}\text { Sub-theme } \\
\text { no. }\end{array}$ & $\begin{array}{l}\text { Description } \\
\text { of sub-theme }\end{array}$ & $\begin{array}{c}\text { Concept } \\
\text { no. }\end{array}$ & $\begin{array}{l}\text { Description of } \\
\text { concept }\end{array}$ & Code no. \\
\hline \multirow[t]{2}{*}{ B } & \multirow[t]{2}{*}{$\begin{array}{c}\text { Economic } \\
\text { barriers }\end{array}$} & \multirow[t]{2}{*}{ B1 } & \multirow[t]{2}{*}{ cost } & B1-1 & $\begin{array}{l}\text { The cost of } \\
\text { facilities for } \\
\text { implementing } \\
\text { green hospitals }\end{array}$ & $\begin{array}{c}\text { E2-A2-C3-F2 } \\
\text { G4 }\end{array}$ \\
\hline & & & & B1-2 & $\begin{array}{c}\text { Cost- } \\
\text { effectiveness }\end{array}$ & $\begin{array}{c}\text { C3-F3-G4-I2- } \\
\text { H4-D3 }\end{array}$ \\
\hline
\end{tabular}

\section{Application of theme analysis}

First, the text of the interviews was carefully implemented and used for analysis. To analyze the text of the interviews, the interview text was first based on the recorded voice of the interviewee, and then it was completed by taking notes during interviewing. Then, by carefully studying these texts, at first, for each of the interviews, all independent ideas were identified in the form of concepts and sub-themes. The most principle themes extracted from the present research are as follows:

\section{Economic barriers}

Frense $e t a l$., addressed a study entitled "going towards greener hospitals in the USA" and concluded that hospitals' plans for being greener are one of the appropriate ways to reduce costs and improve the environment of the hospital for patients and employees. In an interview with hospital staff, economic barriers have been identified as barriers to implement green hospital standards.

\section{Barriers to knowledge and awareness}

So as to reduce damages to patients, surrounding communities and the environment in green hospitals, the managers of hospitals should formulate managerial plans in terms of energy conservation, proper disposal of medical waste and safe management of medicine. In an interview with hospital staff, barriers to awareness and knowledge have been identified as barriers to implement green hospital standards ${ }^{8}$.

\section{Lack of recognition of technology}

The first sub-theme mentioned in Table 4 is the technology's lack of recognition, four concepts was referred to after interviews. The first concept involves "the lack of recognition of technology by employees.

\section{Environmental barriers}

The Green Hospital recognizes the environment and shows it through its management, strategy, and operations. In other words, this kind of hospitals, according to their mission, binds their needs with environmental measures, and by actively contributing to the development, strength of the community's environment and health equity shows its commitment to the environment via adopting preventive measures. According to interviews with hospital staff environmental barriers are considered as ones to the implementation of Green hospital standards. 
Table 3: Conceptual categories regarding awareness and knowledge barriers theme.

\begin{tabular}{|c|c|c|c|c|c|c|}
\hline $\begin{array}{c}\text { Main } \\
\text { theme no. }\end{array}$ & $\begin{array}{c}\text { Description of } \\
\text { main theme }\end{array}$ & $\begin{array}{c}\text { Sub-theme } \\
\text { no. }\end{array}$ & $\begin{array}{c}\text { Description of } \\
\text { sub-theme }\end{array}$ & $\begin{array}{c}\text { Concept } \\
\text { no. } \\
\end{array}$ & $\begin{array}{c}\text { Description of } \\
\text { concept }\end{array}$ & Code no. \\
\hline \multirow[t]{6}{*}{$\mathrm{C}$} & \multirow[t]{6}{*}{$\begin{array}{c}\text { awareness and } \\
\text { knowledge } \\
\text { barriers }\end{array}$} & \multirow[t]{3}{*}{$\mathrm{C} 1$} & \multirow[t]{3}{*}{$\begin{array}{c}\text { Lack of } \\
\text { awareness of } \\
\text { staff }\end{array}$} & C1-1 & $\begin{array}{l}\text { Lack of awareness } \\
\text { of staff regarding } \\
\text { benefits of green } \\
\text { hospital standards }\end{array}$ & $\begin{array}{l}\text { E2-A2-C3- } \\
\text { F2-G4 }\end{array}$ \\
\hline & & & & $\mathrm{C} 1-2$ & $\begin{array}{c}\text { Lack of awareness } \\
\text { of top } \\
\text { management } \\
\text { regarding its } \\
\text { outcomes } \\
\end{array}$ & $\begin{array}{l}\text { C3-F3-G4- } \\
\text { I2-H4-D3 }\end{array}$ \\
\hline & & & & $\mathrm{C} 1-3$ & $\begin{array}{c}\text { Lack of awareness } \\
\text { of staff about } \\
\text { required } \\
\text { technologies }\end{array}$ & $\mathrm{C} 3-\mathrm{H} 2-\mathrm{D} 3$ \\
\hline & & \multirow[t]{3}{*}{$\mathrm{C} 2$} & \multirow{3}{*}{$\begin{array}{c}\text { Unwillingness to } \\
\text { knowledge and } \\
\text { awareness }\end{array}$} & $\mathrm{C} 2-1$ & $\begin{array}{l}\text { Difficult access to } \\
\text { goals }\end{array}$ & $\begin{array}{c}\text { B4-C3-F3- } \\
\text { H2-J3 }\end{array}$ \\
\hline & & & & $\mathrm{C} 2-2$ & $\begin{array}{l}\text { Being satisfied } \\
\text { with current state } \\
\text { of hospital }\end{array}$ & E4-H3-C3 \\
\hline & & & & $\mathrm{C} 2-3$ & $\begin{array}{l}\text { Modeling of } \\
\text { managers for } \\
\text { knowledge } \\
\text { creation }\end{array}$ & $\mathrm{B} 4-\mathrm{C} 3-\mathrm{F} 3$ \\
\hline
\end{tabular}

Table 4: Conceptual categories regarding technological barrier theme.

\begin{tabular}{|c|c|c|c|c|c|c|}
\hline $\begin{array}{c}\text { Main theme } \\
\text { no. }\end{array}$ & $\begin{array}{l}\text { Description } \\
\text { of main } \\
\text { theme }\end{array}$ & $\begin{array}{c}\text { Sub- } \\
\text { theme no. }\end{array}$ & $\begin{array}{l}\text { Description of } \\
\text { sub-theme }\end{array}$ & Concept no. & $\begin{array}{l}\text { Description of } \\
\text { concept }\end{array}$ & Code no. \\
\hline \multirow[t]{4}{*}{$\mathrm{A}$} & \multirow[t]{4}{*}{$\begin{array}{l}\text { Barriers to } \\
\text { technology }\end{array}$} & \multirow[t]{3}{*}{ A1 } & \multirow[t]{3}{*}{$\begin{array}{l}\text { Lack of } \\
\text { recognition of } \\
\text { technology }\end{array}$} & A1-1 & $\begin{array}{l}\text { Lack of } \\
\text { recognition of } \\
\text { technology by } \\
\text { employees }\end{array}$ & $\begin{array}{c}\text { E2-A2-C3- } \\
\text { F2-G4 }\end{array}$ \\
\hline & & & & A1-2 & $\begin{array}{c}\text { Lack of } \\
\text { recognition of } \\
\text { current processes }\end{array}$ & $\begin{array}{l}\text { C3-F3-G4- } \\
\text { I2-H4-D3 }\end{array}$ \\
\hline & & & & A2-3 & $\begin{array}{l}\text { Lack of training } \\
\text { for applying new } \\
\text { technologies } \\
\text { Complex } \\
\text { application of } \\
\text { technology }\end{array}$ & C3-H2-D3 \\
\hline & & A 2 & $\begin{array}{c}\text { Lack of } \\
\text { infrastructures }\end{array}$ & A3-1 & $\begin{array}{l}\text { Making essential } \\
\text { infrastructures to } \\
\text { access the goals }\end{array}$ & $\begin{array}{c}\text { B4-C3-F3- } \\
\text { H2-J3 }\end{array}$ \\
\hline
\end{tabular}

\section{Summarizing extracted themes}

After the study of research literature and interviews with hospital staff and managers, the following main themes and sub-themes were extracted. In the figure below, all main themes (blue) and sub themes (yellow) have been presented. The conceptual model of this research includes five categories of environmental factors (individual environmental barriers and organizational environmental barriers), technology factors (lack of infrastructure and lack of recognition of technology), awareness and knowledge factors (unwillingness to find knowledge and lack of awareness of employees), economic factors (cost) and human resource factors (lack of willingness to change, lack of cooperation, non-commitment,). The results of the ranking of options with TOPSIS technique indicate that the A2 option is superior to other options. The results of ranking by TOPSIS method showed that the barriers to knowledge with $C L$ value $1=1$ were identified as the most important one to implement Green Hospital standards in Imam Hassan Mojtaba Hospital of Darab. The technology barriers index with CL value of 0.690 was in the second place, then the human barriers index with $\mathrm{CL}=0.493$, economic barriers with $\mathrm{CL}=0.39$ and environmental barriers with $\mathrm{CL}=0.223$ were the next priorities.

\section{CONCLUSION}

One of the most important issues that are being discussed globally today is the protection of environment. Studying the standard of the Green Hospital is very important because hospitals are the second most polluting industry in the environment. By applying standards for hospitals, it is possible to help environmental protection. Therefore, the purpose of this study was to identify and prioritize the barriers to implement Green Hospital standards in Imam Hassan Mojtaba Hospital in Darab. 
Table 5: Conceptual categories regarding environmental barriers theme.

\begin{tabular}{|c|c|c|c|c|c|c|}
\hline $\begin{array}{c}\text { Main theme } \\
\text { no. }\end{array}$ & $\begin{array}{c}\text { Description of } \\
\text { main theme }\end{array}$ & $\begin{array}{c}\text { Sub-theme } \\
\text { no. }\end{array}$ & $\begin{array}{c}\text { Description of } \\
\text { sub-theme }\end{array}$ & Concept no. & $\begin{array}{c}\text { Description of } \\
\text { concept }\end{array}$ & Code no. \\
\hline \multirow[t]{3}{*}{$\mathrm{E}$} & \multirow[t]{3}{*}{$\begin{array}{c}\text { Environmental } \\
\text { barriers }\end{array}$} & \multirow{3}{*}{ E2 } & \multirow{3}{*}{ Organizational } & E1-1 & $\begin{array}{c}\text { Lack of } \\
\text { effectiveness of } \\
\text { the activity of } \\
\text { each person }\end{array}$ & $\begin{array}{c}\text { E2-A2-C3- } \\
\text { F2-G4 }\end{array}$ \\
\hline & & & & E2-1 & $\begin{array}{c}\text { Sense of lack of } \\
\text { harms of hospital } \\
\text { wastes }\end{array}$ & $\begin{array}{c}\text { B4-C3-F3- } \\
\text { H2-J3 }\end{array}$ \\
\hline & & & & E2-2 & $\begin{array}{l}\text { Sense of lack of } \\
\text { organizational } \\
\text { effectiveness on } \\
\text { the environment }\end{array}$ & E4-H3-C3 \\
\hline
\end{tabular}

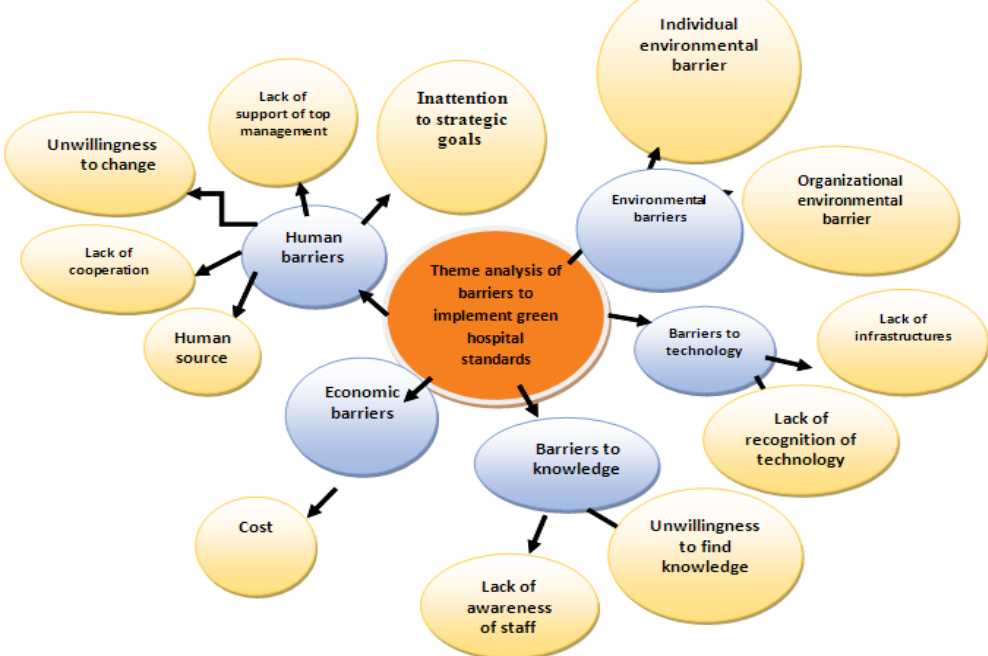

Figure 1: Ranking of options using TOPSIS

The results of this study showed that the conceptual model of this research includes five categories of environmental factors (individual environmental barriers and organizational environmental barriers), technology factors (lack of infrastructure and lack of recognition of technology), knowledge and awareness (unwillingness to find awareness and lack of awareness of employees), economic (costs) and human resource factors (unwillingness to change, lack of cooperation, non-commitment, lack of support from top management and inattention to strategic goals), out of which the barriers to awareness and knowledge were the most important barriers to implement Green Hospital standards in Imam Hasan Mojtaba Hospital in Darab.

Table 6: Ranking of options.

\begin{tabular}{cccccc}
\hline Row & Options & $\begin{array}{c}\text { Distance to } \\
\text { positive } \\
\text { ideal }\end{array}$ & $\begin{array}{c}\text { Distance to } \\
\text { negative } \\
\text { ideal }\end{array}$ & CL & Rank \\
\hline 1 & A1 & 0.067 & 0.065 & 0.493 & 3 \\
2 & A2 & 0 & 0.107 & 1 & 1 \\
3 & A3 & 0.72 & 0.046 & 0.39 & 4 \\
4 & A4 & 0.038 & 0.085 & 0.69 & 2 \\
5 & A5 & 0.096 & 0.028 & 0.223 & 5 \\
\hline
\end{tabular}

In this regard, Ghasemiyeh et al., in a paper titled "Barriers to implement green supply chain management in Bushehr hospitals, mentioned lack of awareness and knowledge as one of the main factors in non-implementation of green activities. Their result was consistent with the present research ${ }^{8}$. Mohebifar et $a l$, in a paper titled "Evaluation of Hamedan hospitals based on the standards of the green hospital in 2015, identified lack of awareness and knowledge as one of the most important obstacles to implement the Green Hospital $^{9}$. Their research result was consistent with the present study. Another result of the present study, which was in the second place, indicates that the lack of recognition of technology is an important obstacle to implement Green Hospital standards. Balaji et al., in a paper on barriers to implement the green supply chain, mentioned lack of recognition of technology as an important barrier to non-implementation of green supply chain management ${ }^{6}$. Their research results are consistent with the present research. Another result of this study is the impact of the lack of infrastructure for IT as one of the most important obstacles to the implementation of Green Hospital standards. Mohammad Jafari et al., in an article on barriers to implement the green supply chain in the industries, stated that lack of infrastructure for information technology is a major obstacle to the implementation of the green supply green supply chain ${ }^{10}$. Their research result was consistent with the present study ${ }^{11}$. Ghasemiyeh et al., in the research on the barriers to implement green supply chain management in Bushehr hospitals pointed out them as one of the most important barriers to implement the green supply chain, and their result is consistent with that of this study ${ }^{8}$. The lack of support of top management was another barrier to 
implement the Green Hospital standards, which was identified in this study. In this regard, Balasubramanian also mentions top management's lack of support as one of barriers to implement green supply chain management, which is consistent with the results of the present study ${ }^{11}$. In a paper entitled Barriers to Implement Green Supply Chain Management in the automobile industry, Luthra et al., mentioned lack of support of top management as an important factor in non-implementation of green supply chain management ${ }^{4}$. The result is consistent with the results of the present study.

Table 7: Ranking of the main barriers.

\begin{tabular}{ccc}
\hline Row & Barrier & Rank \\
\hline 1 & Barriers to knowledge and & 1 \\
& awareness & \\
2 & Barriers to technology & 2 \\
3 & Human barriers & 3 \\
4 & Economic barriers & 4 \\
5 & Environmental barriers & 5 \\
\hline
\end{tabular}

In addition, the results of this study showed that noncommitment is one of the important barriers to implement the Green Hospital. In this regard, Balaji et $a l$. , in a paper entitled "Barriers to implement the green supply chain mentioned non-commitment as an important barrier to non-implementation of the green supply chain ${ }^{6}$. In another study entitled barriers to implement the green supply chain, they consider noncommitment as an important barrier to implement green supply chain management ${ }^{6}$. Balasubramanian consider the top management's non-commitment as the most important barrier to implement the Green Hospital. In another study by Mohammad Jafari et al., on the barriers to implement the green supply chain in industries, they identified non-commitment as an important obstacle ${ }^{10}$. The results of all above studies were consistent with those of the present study ${ }^{11}$.

Another result of this study is the impact of costs as one of the most important obstacles to the implementation of Green Hospital standards. In this regard, Ghasemiyeh et al., referred to the cost of implementation as one of the important obstacles to the implementation of the Green Hospital in a study entitled "Barriers to Implement Green Supply Chain Management in Bushehr Hospitals", which result is consistent with the result of this research ${ }^{8}$. In another study by Mohammad Jafari et al., entitled "Reviewing the Barriers to Implement Green Supply Chain in Industries", the impact of cost on the nonimplementation of the green chain was emphasized. The result of their research was also consistent with that of the present study ${ }^{10}$. Other indicators in the research have not been considered. In this study, they were considered by interviews with experts of Imam Hassan Mojtaba Hospital of Darab. Therefore, it is necessary to recognize the place of implementation of green hospital standards in the health system. Therefore, conduction of this research in other hospitals and identification and removal of barriers to implement Green Hospital standards are recommended to help hospital management initiate strategies that increase the potential of energy saving in the hospital, such as: Creating a culture of energy conservation, the physical role of the hospital building to save energy, and the use of smart control systems, and thus it will further align with the standards of the green hospital. It is also suggested that extra-organizational variables which hinder the implementation of green hospitals should be considered in future studies such as lack of governmental support.

\section{AUTHOR'S CONTRIBUTION}

The manuscript was carried out, written, and approved in collaboration with all authors.

\section{ACKNOWLEDGEMENTS}

The authors extend their thanks and appreciation to the Islamic Azad University, Marvdasht, Iran to provide necessary facilities for this work.

\section{CONFLICT OF INTEREST}

No conflict of interest associated with this work.

\section{REFERENCES}

1. Karliner J, Genther H. A comprehensive environment health care agenda for hospital and health systems around the world. Health care 2011; 1-11.

2. Wood L, Wang C, Abdul-Rahman H, Jamal Abdul-Nasir, N. Green hospital design: integrating quality function deployment and end-user demands'. J Cleaner Production 2015; 1-11.https://doi.org/10.1016/j.jclepro.2015.08.101

3. Esa A, Alma R. Healthy Hospitals, Healthy Planet, 2011.

4. Luthra S, Kumar V, Kumar S, Haleem A. Barriers to implement green supply chain management in automobile industry using interpretive structural modeling techniqueAn Indian perspective. Industrial Eng Manag 2011; 4(2), 231-257.https://doi.org/10.3926/jiem.2011.v4n2.p231-257

5. Dashore K, Sohani N. Green Supply Chain Management: A Hierarchical Framework for Barriers'. Int J Eng Tren Tech 2013; 41(5), 2172-2183.https://doi.org/10.5539/jsd.v5n10p15

6. Balaji M, Velmurugan V, Manikanda P. Barriers In Green Supply Chain Management: An Indian Foundry Perspective. Int J Res Eng Tech 2014; 3(7), 423-430.

7. Omidvar S, Saidi H, Isian Rastegar L, Kouhi Janaghid S. Studying the relationship between the function of green supply chain and operational function by green supply chain management, the first engineering meeting of industries and systems 2015; 1-9.

8. Ghasemiyeh R, Shahbandzade H, Yazdanparast F. The barriers to implement green supply chain management in governmental hospitals of Boushehr, the first International congress of management, economy and development 2015.

9. Mohebifar R, Rouhollah K, Azmal M, Zanganeh Gheshlaghi F. Evaluation of Hamedan hospitals based on green hospital standards in 2015, M.A thesis, 2015. https://doi.org/10.1097/HMR.0b013e31822e2a4f

10. Mohammad Jafari M, Shokrizadeh R, Heidari M, Parvaresh S. Studying barriers to implement green supply chain management in Iranian industries using hierarchical approach.https://doi.org/10.1177/0972150915610701

11. Balasubramanian S. A hierarchical framework of barriers to green supply chain management in the construction sector. J Sustainable Dev 2012; 5(10), 15-28. https://doi.org/10.5539/jsd.v5n10p15

12. Hwang CL, Yoon K. Multiple attributes decision making methods and application. Springer Berlin Heidelberg, 1981. 